\title{
PROBLEMATIKA SLOVENSKEGA PODEŽELJA NA PRIMERU BRKINOV
}

Blaž Barborič, Živa Bobič, Sebastijan Borko, Mina Dobravc, Janez Pirc*

\section{Izvleček}

Brkini predstavljajo slovensko podeželsko pokrajino z mnogimi razvojnimi problemi. Članek analizira prednosti, slabosti, priložnosti in nevarnosti za razvoj regije.

Ključne besede: Brkini, podeželje, pokrajinskoekološka členitev, razvojne možnosti.

\section{PROBLEMS OF SLOVENIAN RURAL AREAS. CASE STUDY OF BRIKINI HILLS}

\section{Abstract}

Brkini region represents underdeveloped Slovene rural area. The article analysis the strengths, weaknesses, opportunities and danger considering regional development.

Key words: Brkini, rural area, ecological units of the region, development opportunities.

\footnotetext{
* Študentje geografije, Oddelek za geografijo, Filozofska fakulteta, Univerza v Ljubljani, Aškerčeva 2, SI 1001 Ljubljana, Slovenija.
} 


\section{Uvod}

Brkini so gospodarsko zaostalo, nerazvito območje, s posebnimi demografskimi in strukturnimi problemi. Zaradi odmaknjenosti so bili v preteklosti zapostavljeni, neupoštevani v regionalnem razvoju in spadajo med marginalna slovenska območja. Predvidevamo, da je za nadaljnji pozitivni razvoj Brkinom potrebno posvetiti posebno pozornost, aktivirati razpoložljive človeške vire (državo, občine, lokalno prebivalstvo), izdelati razvojne programe in zanje pridobiti finančna sredstva.

Brkine smo izbrali za raziskovalni projekt zaradi pokrajinske zaokroženosti, odmaknjenosti, slabšega poznavanja in predvsem, ker nam izbrano območje predstavlja raziskovalni izziv. Zastavili smo si naslednje cilje: ugotoviti družbenogeografske in fizičnogeografske značilnosti in procese izbranega območja, izdelati pokrajinskoekološko členitev območja in funkcijsko vrednotiti posamezne pokrajinskoekološke enote, podrobneje spoznati nekatera naselja ter končno na osnovi pridobljenih informacij ter vrednotenja s SWOT analizo predlagati prihodnji razvoj območja in predlagati prioritetne cilje.

Ključno vprašanje, ki smo si ga zastavili, je bilo, kateri dejavniki lahko pomembno vplivajo na prihodnji razvoj Brkinov. Na osnovi opravljenih splošnih analiz smo izdelali SWOT analizo, kjer smo sintetično predstavili prednosti, slabosti, priložnosti in nevarnosti in jih razvrstili po prioriteti.

\section{Meje Brkinov}

V naši raziskavi se nam je pogosto pojavilo vprašanje do kod segajo Brkini. Do sedaj je bilo opravljenih že več regionalizacj Slovenije, vendar v nobeni členitvi niso Brkini kot samostojna regija. Najpogosteje so bili Brkini vključeni v regijo "Brkini in dolina Reke". Na severovzhodni strani je meja vprašljiva na stiku Brkinov z dolino Reke, kjer kot glavni kriterij predlagamo stik pobočja z dolinskim dnom reke Reke. Na severozahodni in jugozahodni strani Brkinov je možnosti za izbor kriterijev in omejitev več. Brkine bi lahko omejili na tisto območje, katerega matična podlaga je eocenski fliš, apnenčasti del pa bi izločili iz omejene regije. Prednost tega kriterija je v tem, da bi bili Brkini notranje fizičnogeografsko bolj homogeni in bi se ime Brkini nanašalo na flišna pobočja in slemena. Slabost te razmejitve je, da se reliefno pobočja in slemena predvsem na severozahodnem delu neprekin- 
jeno nadaljujejo tudi na apnenčastem delu. Tako bi bil del slemen in pobočij na apnencu, ki so sedaj vključeni v Brkine, po tem kriteriju izločeni. Drug kriterij, ki bi ga lahko uporabili za določitev severozahodne in jugozahodne meje, je prav tak kot na severovzhodni strani, to je stik pobočja z bolj uravnanim svetom. Tako bi v regijo in pojem Brkini vključili tudi tista pobočja in slemena, ki so na apnencu. Problem bi nastal pri natančnejšem določanju meje, saj ni vedno povsem jasno določljiv stik pobočja z bolj uravnanim delom. Potrebno bi bilo tudi napraviti analizo pripadnosti prebivalcev posameznih naselij, ali se štejejo za Brkince ali imajo razvito drugo lokalno identiteto. Tako bi lahko natančneje določili mejo na jugozahodni strani, kjer je niz naselij ob magistralni cesti. V naši raziskavi smo Brkine omejili na naslednji način. Na jugozahodni strani poteka meja po magistralni cesti, ki poteka na stiku Matarskega podolja in Brkinov. Na severozahodni strani smo mejo začrtali na prehodu med pobočji z večjim naklonom in uravnavami z manjšim naklonom. Na severni in severovzhodni strani smo po celotni dolžini mejo potegnili na stiku pobočja Brkinov in dolinskega dna reke Reke. $\mathrm{Na}$ jugovzhodni strani pa mejo določa državna meja med Slovenijo in Hrvaško.

\section{Prehodnost regije kot razvojni potencial}

Brkini ležijo na prehodu med submediteransko in celinsko Slovenijo, kar se kaže predvsem v podnebnih razmerah (prehodnost podnebja). Specifičnost lege Brkinov se kaže tudi v relativni bližini in relativni oddaljenosti pomembnih prometnih tokov Slovenije. Preko regije ne poteka nobena magistralna ali regionalna cesta; tako ceste $v$ Brkinih spadajo po hierarhiji med lokalne ceste. Vendar so $v$ neposredni bližini regije kar tri pomembne prometne poti v Sloveniji. Najpomembnejša povezava je avtocesta, ki je glavna prometna os Slovenije $v$ smeri severovzhod - jugozahod, poteka od Ljubljane proti Kopru in se na severozahodu Brkinom približa. Na jugozahodni strani poteka magistralna cesta med Trstom in Reko, oziroma najkrajša povezava Hrvaške z Evropsko skupnostjo. Pomembna prometna pot poteka na vzhodu Brkinov, kjer od Pivke, preko llirske Bistrice do Opatije poteka druga pomembna pot Slovenije proti Hrvaški. Ne glede na relativno bližino omenjenih prometnic, so Brkini oddaljena in odmaknjena regija, tako prostorsko, predvsem pa miselno. Notranjo prehodnost slabi reliefna razčlenjenost in temu primerna šibka prometna infrastruktura. Priložnost z vidika lege Brkinov vidimo $v$ relativni bližini Jadranske obale. Istra je poletna turistična destinacija srednje Evrope in možen vir turistov za Brkine. Brkini tudi predstavljajo naravno zaledje Trsta, ki kot srednje veliko 
mesto potrebuje zaledje za rekreacijo in ostale funkcije. V Brkine se že sedaj med vikendi odpravlja mnogo Tržačanov, kjer se rekreirajo na različne načine (npr. ribolov, gobarjenje). Turistični potencial Brkinov pa zmanjšujejo bližnji priznani in uveljavljeni turistični centri, kot so Lipica, Škocjanske jame in druge turistične destinacije.

\section{Pokrajinskoekološka členitev Brkinov}

Za potrebe načrtovanja nadaljnjega razvoja Brkinov in razvojnih možnosti regije smo izdelali pokrajinskoekološko členitev Brkinov. Pokrajinskoekološka členitev nam je služila kot fizičnogeografska podlaga pri vrednotenju nadaljnjega razvoja in pri konkretnem umeščanju razvojnih možnosti $v$ prostor, kjer se bodo pokazale fizičnogeografske ovire, nevarnosti, pa tudi prednosti in priložnosti. Pokrajinskoekološka členitev Brkinov je oblikovana na osnovi naslednjih kriterijev: geološko-litološke zgradbe, reliefa, vegetacije in rabe tal, podnebja in vodnih razmer. Pokrajino smo razdelili na šest enot in nekatere izmed njih na podenote.

1. Slemena na Brkinih. So najbolj markantni deli Brkinov. Slemena na Brkinih so se pokazala kot pokrajinskoekološka enota z največjim razvojnim potencialom. $V$ celoti so nad območjem toplotnega obrata, $v$ termalnem pasu. Nakloni so med $0-5^{\circ}$, največ $12^{\circ}$, kar je ugodno za kmetijsko obdelovanje. Prst (ranker) je na temenih zaradi majhnih naklonov globlja (do 0,5 $\mathrm{m}$ ) kot na pobočjih na flišu. Zaradi toplotnih, reliefnih ter drugih ugodnih fizičnogeografskih razmer (prst) so na slemenih zelo ugodne lege za razvoj sadjarstva. Značilna slemenskost, nadmorske višine nad toplotnim obratom (kar pomeni manj slane, manj dni z meglo in podobno) in razglednost je prednost Brkinov, ki lahko pomaga pri razvoju specifičnih turističnih dejavnosti (npr. kolesarske steze). V tej pokrajinskoekološki enoti je tudi glavna poselitvena os, ki poteka po temenih slemen. Slepe doline, pobočja v flišu, pritoki reke Reke so zaradi neprimernih fizičnogeografskih in prostorskih razmer neprimerni za poselitev. Veliko nevarnost tej enoti predstavlja intenziven proces zaraščanja. Zaradi negativnih demografskih gibanj je hkrati potekal proces opuščanja obdelovalnih površin (opuščanje košnje, paše, sadovnjakov, njiv itd.) ter posledično hitro zaraščanje. Gozd se širi iz ozkih grap in pobočij proti temenom slemen. Zaraščanje zmanjšuje vrednost kulturne pokrajine, slabša doživljajske zmožnosti turistov, poslabša se razglednost, posledično se s tem zmanjšajo turistični potenciali tega območja. Rekultivacija zahteva visoke začetne investicije, kar je odbi- 
jajoče za potencialne obdelovalce in uporabnike tega območja. Brkini spadajo v žledni pas Slovenije. Katastrofalni žled se $v$ Brkinih pojavi na vsakih 30 let (zadnji leta 1980). Najpogosteje se pojavlja na nadmorski višini med $500 \mathrm{~m}$ in $800 \mathrm{~m}$, večja intenzivnost pa na izpostavljenih robovih slemen. Nastanek žleda je pogojen z lego Brkinov, kjer se mešajo vplivi sredozemskega in celinskega podnebja. Težak ledeni oklep ledu povzroča lom drevja $v$ sadovnjakih in gozdu ter poškodbe na električnih daljnovodih. Zaradi omenjene pogostosti in intenzivnosti je potrebno žled upoštevati pri nadaljnjem načrtovanju regije, predvsem na slemenih.

2. Pobočja v flišu. Zaradi velikih naklonov pobočij, plitve prsti in močne gozdnatosti ima pokrajinskoekološka enota pobočja $v$ flišu zelo omejene možnosti nadaljnjega razvoja. Zaradi gozdnatosti Brkinov je v gozdovih veliko divjadi in gob. Turistični lov in gobarjenje lahko pomenita razvojno priložnost ali pa nevarnost.

3. Slepe doline. Na stiku apnenca in fliša so se razvile posebne geomorfološke oblike kontaktnega krasa. Na jugozahodnem delu Brkinov se je razvil niz slepih dolin (Brezovica, Odolina, Hotičina, Velike Loče, Jezerine, Oslica in druge), ki imajo hidrološke in geomorfološke posebnosti. Oblike kontaktnega krasa in njihove posebnosti bi lahko izkoristili kot posebno turistično ponudbo $v$ kontekstu $s$ kraškimi oblikami $v$ apnenčastem delu Brkinov. Značilnost slepih dolin predstavljajo poplave pred ponori, oglejena prst in reliefna zaprtost. Tipična je tudi prostorska omejenost, zato so se le v nekaj slepih dolinah lahko razvila naselja, v večini pa so slepe doline neprimerne za poselitev. Priložnost predstavljajo uravnana dna slepih dolin, kjer so travniki primerni za živinorejo (konjereja je že prisotna).

4. Apnenčasti del Brkinov. Velik razvojni potencial tega območja predstavljajo kraške oblike (jama Dimnice), ki jih je mogoče uporabiti v turistične namene. Zaradi plitvosti prsti in hitrega odtoka padavinske vode $v$ matično podlago je prst manj primerna za kmetijsko obdelovanje. Tako so že v preteklosti rabili tla predvsem za pašo in travnike. Danes zaradi opuščanja paše in košnje travnikov poteka proces intenzivnega zaraščanja.

5. Dolinsko dno reke Reke in njenih pritokov z Brkinov. Dolinska dna pritokov reke Reke iz Brkinov imajo zelo omejene možnosti za nadaljnji razvoj in kakršnokoli rabo. Dna pritokov so prostorsko omejena in ozka, obdana s strmimi pobočji v flišu. Dolinsko dno reke Reke po našem mnenju ne spada $v$ območje Brkinov in ga zaradi tega nismo posebej obravnavali v naši nalogi. 
6. Dolina s pliocensko matično podlago. Tudi te enote nismo obravnavali kot del Brkinov in je zato nismo vključili v našo raziskavo.

Karta 1: Pokrajinskoekološke enote Brkinov.

Map 1: Ecological units of Brkini hills.

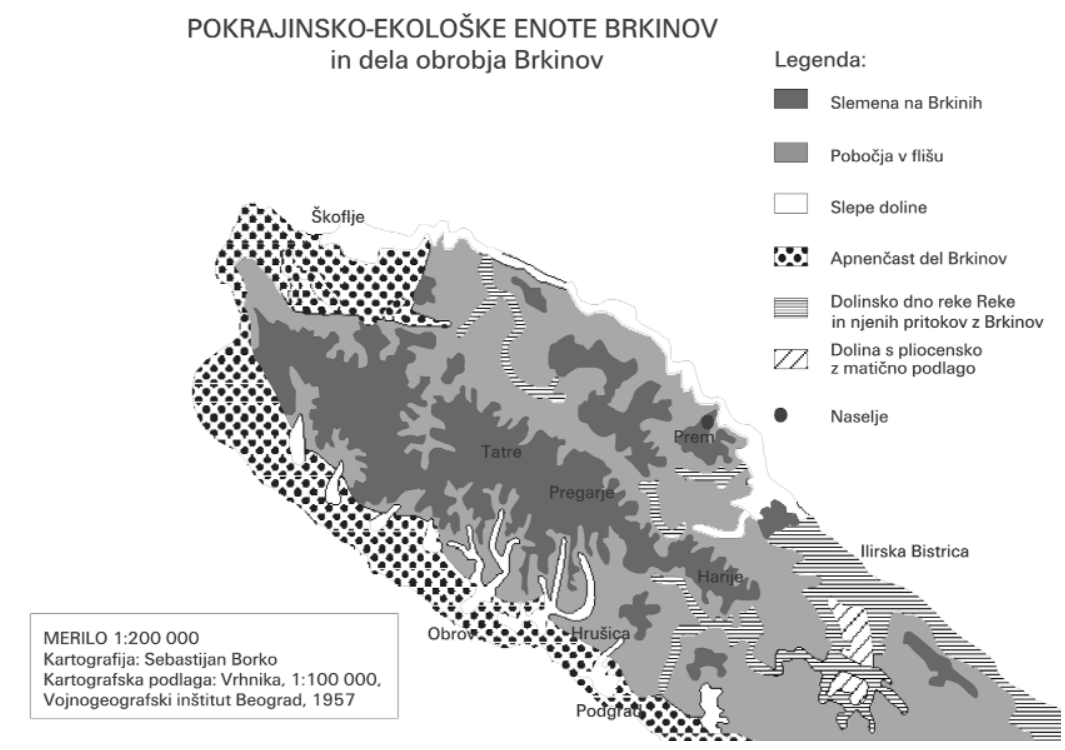

\section{PREBIVALSTVO IN NASELJA BRKINOV}

Gospodarski razvoj Trsta v začetku 20. stoletja je vplival na porast števila prebivalcev na območju Brkinov. Največje število prebivalcev je bilo med letoma 1890 in 1910 (15 000). Odtlej se je število prebivalcev naglo zmanjševalo. Splošna gospodarska, predvsem pa agrarna kriza je pomenila množično izseljevanje $v$ primorska mesta (Trst, Reka) in čezmorske dežele. $\mathrm{K}$ hitremu propadanju pokrajine sta na začetku 20. stoletja največ pripomogli prva svetovna vojna in italijanska okupacija, kasneje druga svetovna vojna in nazadnje še priključitev Trsta k Italiji leta 1953. Prebivalci so množično sodelovali v narodnoosvobodilnem boju, zato so se po 2. svetovni nadejali pomoči jugoslovanske države. Ta je bila preskromna, da bi območju zagotovila razvoj in zmanjšala odseljevanje (Barbič, 1996).

Leta 1991 je živelo na območju Brkinov le še 7469 prebivalcev, kar je polovico manj kot I. 1910. Statistični podatki za december 2000 kažejo še nadaljnje upadanje števila prebivalcev.V Brkinih je živelo 7116 prebivalcev. 
Grafikon 1: Gibanje števila prebivalcev Brkinov po posameznih obdobjih.

Fig. 1: Population growth at Brkini hills.

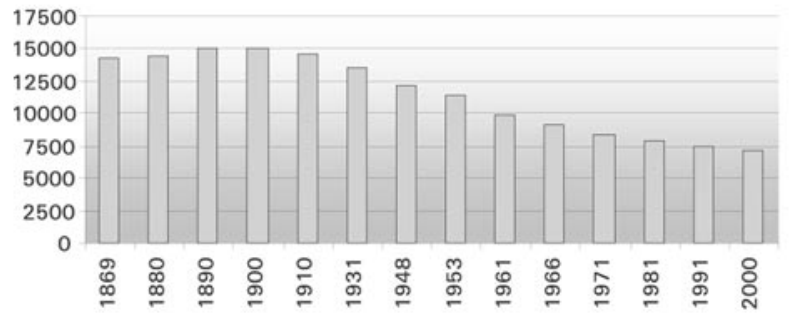

Vir/Source: Geografski vestnik, 1996, Statistični urad Republike Slovenije, december 2000.

Upadanje skupnega števila prebivalstva je najbolj očitno, če pogledamo podatke o gibanjih prebivalstva znotraj 30 krajevnih skupnosti (Barbič, 1996):

- porast prebivalstva je $v$ zadnjem desetletju ali dveh opaziti le v dveh večjih krajevnih skupnostih (KS): Hrpelje, Podgrad in dveh manjših KS: Rečica in Rakitovec;

- zaustavitev padanja števila prebivalstva v petih KS: Artviže, D. Bitnje, Divača, Koseze in Rodik;

- zmanjševanje prebivalstva znotraj 21 KS (Barbič, 1996).

Upadanje se je nekoliko umirilo v obdobju 1981-2000. Razloge gre iskati v dejstvu, da je najbolj vitalni del prebivalstva do začetka 80 . let 20. stoletja že zapustil območje Brkinov, pa tudi v zmanjševanju števila razpoložljivih delovnih mest $v$ začetku 90. tih let ob prehodu Slovenije $v$ tržno gospodarstvo.

Za prikaz starostne sestave prebivalstva smo uporabili indeks staranja. Pri idealnem demografskem razvoju naj bi bil ta okrog 40. Indeks 72 predstavlja t.i. demografski prag. Ko je ta presežen, lahko pričakujemo zmanjševanje števila prebivalcev tudi v primeru, da vsi mladi prebivalci ostanejo doma. Indeks staranja za območje Brkinov (Is) je leta 1991 znašal 97 (tabela 1), leta 2000 pa 103, kar kaže na vedno večjo prevlado starejših prebivalcev. Potrebni bodo ukrepi občin in države, da se bodo Brkini populacijsko ustalili in revitalizirali. Delež prebivalcev nad 60 let ponekod že presega $30 \%$. Vse do osemdesetih let je nazadovanje prebivalstva povzročalo 
predvsem izseljevanje, v zadnjem desetletju pa se je rodnost prepolovila (I. 1991: 0,8 \%) in je že manjša od smrtnosti.

Tabela 1: Število in deleži prebivalcev po posameznih starostnih kategorijah ter indeksi staranja za območje Brkinov in Slovenijo za leto 1991 in 2000.

Tab. 1: Number and share of inhaboitants according to age structure at Brkini hills and Slovenia, 1991 and 2000.

\begin{tabular}{|l|c|c|c|c|c|}
\hline & Št. preb. & $0-14$ let (\%) & $15-64(\%)$ & 65 in vec (\%) & IS \\
\hline $\begin{array}{l}\text { Brkini } \\
(1991)\end{array}$ & 7.469 & 17,9 & 64,7 & 17,4 & 97 \\
\hline $\begin{array}{l}\text { Brkini } \\
(2000)\end{array}$ & 7.116 & 12,6 & 74,4 & 13,0 & 103 \\
\hline $\begin{array}{l}\text { Slovenija } \\
(1991)\end{array}$ & 1.965 .986 & 20,6 & 65,5 & 10,9 & 53 \\
\hline
\end{tabular}

Vir/Source: Popis prebivalstva 1991, Statistični urad Republike Slovenije, december 2000.

Izobrazbena raven prebivalstva $\vee$ Brkinih je bila I. 1991 precej pod slovenskim povprečjem. 35,5\% prebivalcev ni končalo osemletne osnovne šole, kar je mnogo več, kot znaša povprečje Slovenije (17,3 \%; Barbič,1996).

Tabela 2: Izobrazbena raven prebivalcev starejših od 15 let za območje Brkinov leta 1991.

Tab. 2: Level of education over 15 years old inhabitants at Brkini hills, 1991.

\begin{tabular}{|l|c|c|c|c|}
\hline & $\begin{array}{c}\text { Nedokončana OŠ } \\
(\%)\end{array}$ & OŠ (\%) & $\begin{array}{c}\text { SŠ in poklicna } \\
\text { šola (\%) }\end{array}$ & $\begin{array}{c}\text { Višja in visoka } \\
\text { šola (\%) }\end{array}$ \\
\hline Brkini & 35,2 & 27,9 & 33,6 & 3,2 \\
\hline Slovenija & 17,3 & 30,3 & 43,4 & 8,9 \\
\hline
\end{tabular}

Vir/Source: Popis prebivalstva 1991.

Primerjava izobrazbene strukture med posameznimi KS kaže, da je le-ta bolj ugodna v KS Hrpelje, Gradišče in Rodik. Prebivalci teh krajev so bliže delovnim mestom $v$ večjih središčih in ta so bolj privlačna kot vsakodnevna vožnja v kraj zaposlitve in nazaj. Med dnevnimi migranti prevladujejo nižje kvalificirani in kvalificirani delavci.

Povprečno število članov gospodinjstvev v Brkinih je bilo po popisu I.1991 3,0 (povprečje za Slovenijo znaša 3,1). 
V KS Artviže je bilo I. 1991 največ kmečkih gospodinjstev, ki pridobivajo dohodek samo iz kmetijstva (38,5 \%; Barbič, 1996).

Danes prebivalci Brkinov pridelujejo le živež za lastne potrebe, travniki in pašniki pa se v vedno večjem obsegu zaraščajo v gozd slabše kvalitete.

Največ je naselij z manj kot 300 prebivalcev, v katerih živi večina ljudi. Gostota poselitve je bila I. 1991 le 25 prebivalcev na km2. V povprečju je prebivalo $v$ naselju 105 prebivalcev. Z nadmorsko višino se gostota poselitve in povprečna velikost naselij zmanjšujeta, izjema je višinski razred nad 700 m, kjer je povprečna velikost naselij zaradi lege krajev vrh slemen nekoliko večja. Večja naselja so na pokrajinskem stiku (apnenec - fliš), kjer potekajo pomembnejše cestne povezave in je več ravninskega sveta.

Pokrajinsko središče Brkinov je vas Pregarje. To je razpotegnjeno naselje z več strnjenimi deli in stoji na osrednjem slemenu Brkinov. Je centralni kraj 1. stopnje (Vrišer, 1998). Upadanje prebivalstva se je po letu 1961 nekoliko umirilo, kljub temu se število prebivalcev še vedno zmanjšuje (I.1991 je bilo 243 preb., I. 2000 pa 225 preb.).

Naselja v Brkinih imajo značilno slemensko lego. Postavljena so tam, kjer je sleme bolj ozko in strmo (Pregarje, Huje, Tominje, Prelože itd.), v vzhodnih Brkinih pa predvsem na vrhu kopastih vzpetin (Sabonje, Podbeže, Veliko Brdo). Skoraj vsaka slepa dolina ima na robu svoje naselje (Novokračine, Male Loče, Velike Loče, Slivje, Hotična, Brezovica, Vremski Britof itd.)

Za večino naselij je značilna strnjena gručasta pozidava, saj se tako ohrani največ kmetijskih površin. Vasi so $v$ večini podolgovate, razpotegnjene. Vaška jedra so razpotegnjena vzdolž osrednje prometnice (npr. Harije, Mrše). Večina tradicionalnih hiš je zgrajenih iz fliša, ki v novejšem času propadajo. Med leti 1948 in 1968 se je število hiš v Brkinih zmanjšalo za petino (Pokrajine in ljudje, 1998).

Nekateri prebivalci se vračajo na območje Brkinov. Ponekod tradicionalne kmečke hiše spreminjajo $v$ počitniške hiše. S tem se spreminja funkcija domov in tudi videz naselij in pokrajine. Naselja $s$ kmečkimi domovi in gospodarskimi poslopji so se $v$ zadnjih treh desetletjih spremenila v večinoma spalna naselja. Ta proces je posledica zmanjševanja števila kmečkega prebivalstva in dnevne migracije $v$ večja zaposlitvena središča. Prebivalstvo Brkinov se je po izrazitem zmanjšanju števila ob popisu 1961 le počasi zmanjševalo. Glede na socialni položaj prebivalcev, razmeroma visok delež zaposlenih in dobro prometno povezanostjo z zaposlitvenimi 
središči ter trenutnim stanjem prebivalstva lahko ugotovimo, da se bo število prebivalcev še naprej počasi zmanjševalo in staralo.

\section{Gospodarski položaj Brkinv}

Po podatkih popisa leta 1991 je bilo na območju Brkinov zaposlenih 44,7 \% vseh prebivalcev, kar je razmeroma visok delež, saj je višji od takratnega slovenskega povprečja (40,9 \%). Takšen delež zaposlenih v Brkinih gre pripisati vsaj dvema razlogoma (Barbič, 1996): nizkemu deležu otrok oz. visokemu deležu odraslih in dnevni migraciji na delo $v$ bolj oddaljena središča. $V$ Brkinih je bilo namreč istega leta tudi več dnevnih delovnih migrantov (59,7\%) kot je bilo slovensko povprečje (55,3\%; Barbič, 1996). Pomemben dejavnik zaposlovanja $v$ večjih zaposlitvenih središčih je leta 1978 zgrajena slemenska cesta. Zaradi pomanjkanja delovnih mest v samih Brkinih se prebivalci zaposlujejo $v$ občinskih središčih (Ilirska Bistrica, Hrpelje-Kozina, Divača in Pivka), v obalnih mestih, nekaj pa jih dnevno migrira tudi $v$ Ljubljano1. Posledica dnevnih migracij je, da se naselja preobražajo v spalna naselja. V primeru, da se prebivalstvo za stalno izseli, pride do propadanja stavb, kar je viden pojav v nekaterih brkinskih naseljih.

V Brkinih se je hkrati z zmanjševanjem števila prebivalstva nižal tudi delež kmečkega prebivalstva - med letoma 1961 in 1991 se je zmanjšal s 40,7 \% na 9,1 \%, kar je nekoliko nad državnim povprečjem. Največ kmečkih gospodinjstev, ki pridobivajo dohodek samo iz kmetijstva, je bilo I. $1991 \mathrm{v}$ KS Artviže, in sicer 38,5 \% vseh gospodinjstev (Barbič, 1996). Razlog za opuščanje kmetovanja danes predstavlja tako odseljevanje mladih in s tem razkroj kmečkih gospodinjstev, ki tako ostanejo brez naslednikov, kot tudi italijanske pokojnine, ki zagotavljajo preživetje brez dodatnih virov zaslužka ${ }^{1}$.

Zaposlitvena središča Brkincev so povezana z obmejno lego območja, ki je spodbudila razvoj gostinskih in servisnih dejavnosti predvsem $v$ Podgrajskem podolju, ob cesti Reka - Kozina - Trst. V Podgradu je tudi zelo pomemben obrat Plana (proizvodnja plastičnih mas), ki zaposluje med 800 in 1000 ljudi, predvsem z Brkinov. Prehodni potniki predstavljajo potencialni vir zaslužka, ki bi lahko bil usmerjen $v$ bolj intenzivni razvoj turističnogostinskih dejavnostih.

\footnotetext{
1 Ustni vir: gospa Nevenka Tomšič, občina llirska Bistrica, april 2001.
} 


\section{Zunanji dejavniki Brinov}

Veliko slabost Brkinov predstavlja razdeljenost med štiri občine: Divačo, Ilirsko Bistrico, Hrpelje-Kozino in Pivko. Med njimi ni sodelovanja in zato ni skupne strategije razvoja Brkinov. $V$ vseh naštetih občinah Brkini predstavljajo periferno, nerazvito območje. Ta zaviralni dejavnik bi bilo v prihodnje nujno potrebno odpraviti.

Za sofinanciranje izvedbe določenih projektov za razvoj Brkinov se trenutno koristita dva vira: programi CRPOV in PHARE. Programi CRPOV so bili že leta 1992 sprejeti za KS Hrušica in Prem. Denar je namenjen urejanju poljskih poti, prenovi gradu Prem, ureditvi Kettejeve sobe, uvedbi blagovne znamke. Letos je bila $v$ vasi Barka predstavitev in posvetovanje o programu CRPOV. Iz razgovora s predsednikom KS je bilo razumeti, da naj bi se $v$ omenjeni program letos vključili dva ali trije vaščani. Iz sredstev programa PHARE je bila dograjena komunalna infrastruktura².

Posledice, ki jih bo čutiti na Brkinih ob priključitvi Slovenije Evropski zvezi, lahko vrednotimo $z$ večih vidikov. Ob odprtju meje z Italijo bo možno ponovno povezovanje Trsta $z$ njegovim zgodovinskim zaledjem, katerega pomemben del so tudi Brkini. Brkinske kmetije pa za sedaj še niso konkurenčne tržnim kmetijam $\vee$ Evropski skupnosti, kar bi lahko po priključitvi pomenilo množičen propad kmetij in posledično opuščanje obdelovalnih površin, pospešeno zaraščanje in praznenje podeželja.

\section{Razvojne možnosti Brkinov}

Kmetijstvo je še danes ena najpomembnejših gospodarskih panog $v$ Brkinih. Tu ima dolgo tradicijo in velik pomen za njegov zgoden razvoj imajo ugodni naravni dejavniki.

Največji del kmetijskih dejavnosti se odvija na nadmorski višini nad 500 m, kjer se začne tudi toplotni pas in kot npr. sadjarstvo segajo še nad zgornji rob toplotnega pasu, na višini $700 \mathrm{~m}$. Podlaga je flišna. Povprečna temperatura v dobi vegetacije je okoli $14^{\circ} \mathrm{C}$, povprečna letna višina padavin pa med 1200 in $1450 \mathrm{~mm}$ (Adamič, 1990). Omenjene naravnogeografske lastnosti in pa velika temperaturna razlika med dnevom in nočjo (Brkinska sadna pot, 1998) pomenijo dobre

2 Ustni vir: gospod Srečko Sanabor, april 2001. 
pogoje za veliko kmetijskih kultur, zlasti pa za sadjarstvo.

Problematični pa so že omenjeni pojavi in procesi: možnost katastrofalnega žleda, burje ter splošnega zaraščanja z gozdom, ponekod pa tudi erozije prsti. Za Brkine so značilne kulturne terase, ki pa služijo tudi za preprečevanje erozije.

Razvoj kmetijstva skozi preteklost pa do danes bi lahko razdelili na tri faze: - Prva faza obsega čas od začetka 18. stoletja do 1. svetovne vojne. Začetek te faze se ujema z razvojem pristanišč $v$ Trstu in na Reki, ko so se Brkini naglo začeli razvijati kot njuno zaledje (Barbič, 1996). Tako so mestoma dobavljali različne kmetijske pridelke, zlasti sadje, mleko, živino in tudi drva (Pokrajina in ljudje, 1998), brkinski proizvodi pa so prodrli skozi pristanišča vse do Dalmacije (Barbič, 1996).

Intenzivno sadjarstvo se je na Brkinih začelo že v 19. stoletju. Sredi 19. stoletja je bila že ustanovljena drevesnica na Premu, Janez Bleiweis pa je leta 1857 organiziral zbor sadjarjev v Ilirski Bistrici. Takrat so sprejeli tudi sadni izbor za Brkine. Šele konec 90. let 19. stoletja je v severnem delu prevladala pridelava jabolk. V tem času so brkinsko sadje, zlasti jabolka in češplje spoznali tudi na sadjarskih razstavah po Evropi. Leta 1912 je bila prva sadjarska razstava na območju Brkinov organizirana v Trnovem pri Ilirski Bistrici, kjer so sadjarji dokončno izbrali rodovitne in za trgovino primerne sorte (Brkinska sadna pot, 1998).

- Druga razvojna faza kmetijstva je trajala od obdobja med svetovnima vojnama pa do nastanka slovenske države. V času do druge svetovne vojne je regija spadala pod Italijo in kot taka še naprej imela močne vezi s pristaniščema. Sadjarji so do druge svetovne vojne sadje sušili v Vremah2. Po vojni je sadjarstvo skoraj v celoti zamrlo. Zaradi nove državne meje z Italijo, so Brkini tudi izgubili pomembno tržišče za kmetijske pridelke. Konec 50. in v začetku 60. let 20. stoletja je prišlo do dveh neuspelih poizkusov obnove intenzivnega sadjarstva na severozahodnem območju. Razlog za neuspeh je bilo treba iskati zlasti v menjavi in odhodu kvalificiranih sadjarjev (Adamič, 1990).

Do konca 70. let je bilo kmetijstvo v Brkinih najpomembnejša gospodarska panoga (Pokrajina in ljudje, 1998).

- Začetek tretje razvojne faze omejuje nastanek samostojne Slovenije in s tem tudi postavitev državne meje s Hrvaško. To je pomenilo zopet izgubo pomembnega trga za domače pridelke in tako tudi še večjo marginalizacijo območja. 
Nekdaj je bila od živinoreje pomembna ovčereja, danes pa prevladuje govedoreja, čeprav je le-ta od leta 1991 v krizi. Vzroke za to lahko najdemo tudi v zmanjšanju prekomejne prodaje po izoblikovanju nove državne meje. $\mathrm{Na}$ poljih danes prideljujejo koruzo, pšenico, rž, ječmen in krompir. V strukturi rabe zemljišč se je $v$ zadnjih desetletjih najbolj očitno spremenil delež gozda, katerega površina se je povečala zlasti na račun zaraščanja travnikov in pašnikov. Še naprej prihaja do opuščanja obdelovalnih površin (Barbič, 1996).

Grafikon 2: Struktura rabe zemljišč v Brkinih leta 1955 in 1995.

Graf. 2: Land use structure at Brkini hills, 1955 and 1995.
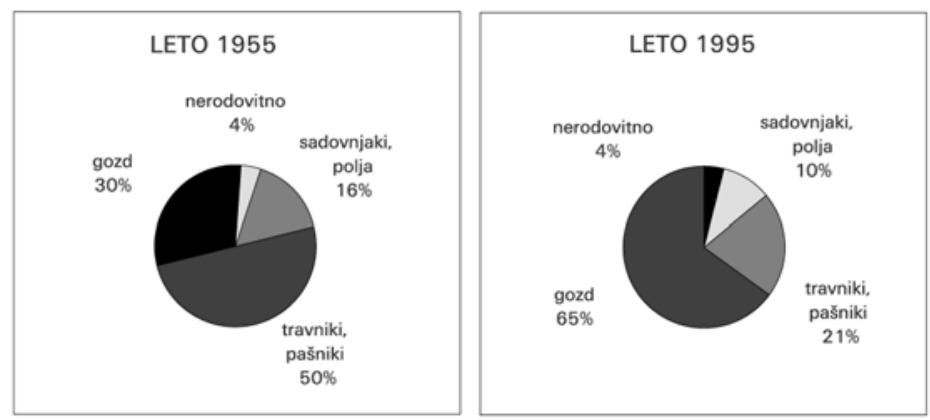

Vir/Source: Barbič, 1996.

Brkini so danes znani po pridelovanju jesenskih in zimskih jabolk, sliv, češpelj, višenj, poznih češenj, orehov in lešnikov. Poleg Slovenskih goric je to najobsežnejše območje za pridelovanje jesenskih in zimskih jabolk.

Ta se pridelujejo $v$ severovzhodnih flišnih predelih Brkinov: in sicer na območju Prema (od vasi Zarečje - Smrje - Janževo Brdo - Ostrožno Brdo), na območju Košane (Nove in Stare Šušice do Košane) ter na območju Vremske doline (od Ribnice do Vremskega Britofa in od Barke do Vatovelj). Slive, češplje, češnje in višnje uspevajo na jugozahodnem in osrednjem območju Brkinov: od Podgrada preko Hrušice in Obrova do Materije oziroma od Harij in Pregarij čez Tatre do Artviž.

$\mathrm{Na}$ južnem kraškem obrobju Brkinov pa gojijo orehe in lešnike (Adamič, 1990).

Danes se s sušenjem sadja za prodajo ukvarja le še g. Srečko Sanabor iz Harij. Leta 1997 je dobil tudi sredstva iz sklada CRPOV. Suši slive in jabolka, prideluje pa tudi naravni jabolčni kis in jabolčno vino, prodaja pa seveda tudi sveže sadje. Je dobitnik dveh zlatih in enega srebrnega priznanja za svoje izdelke. 
Pričakovati je, da bo brkinsko kmetijstvo po vstopu Slovenije v EZ še bolj izgubilo na pomenu, saj zaradi razgibanega reliefa, staranja prebivalstva in zemljiške strukture ne bo moglo biti konkurenčno kmetijstvu EZ.

Ukrepi za spodbujanje kmetijstva se z različnimi sofinancerskimi programi EZ in ministrstev uvajajo že več let. Prihodnost kmetijstva na Brkinih pa ne vidimo le skozi te programe. Izobrazba, upoštevanje lokalnih značilnosti in tradicije, predhodna raziskava trga, inovativnost in organiziranost so se $v$ primeru g. Sanabora izkazale kot zelo uspešne in to kljub temu da se je g.Sanabor šele pred nekaj desetletji preselil na omenjeno območje. Srečko Sanabor prodaja biološko neoporečno sadje, tako suho kot sveže oziroma predelano $v$ različne izdelke. Povpraševanja po tako gojenem sadju je veliko in še je pričakovati porast, temu primerno pa so tudi cene višje od "navadnega" sadja.

V t.i. biokmetijstvu vidimo prihodnost kmetijstva Brkinov. Tako bi se lahko tudi zaustavil zaraščanje in propadanje kulturne pokrajine.

\section{Turizem v Brkinih}

Menimo, da je pri razvoju turizma na obravnavanem območju pomembno tudi privabljanje oz. zaustavitev glavnih turističnih tokov, ki gredo po avtocesti mimo Brkinov. Zato bi bilo potrebno postaviti turistične (večjezične) informativne table že ob samem izvozu z avtoceste pri Kozini. Tudi na samih Brkinih ni nobenih informacijskih tabel in smerokazov, ki bi usmerjali in informirali obiskovalce o naravnih in kulturnih znamenitostih. Veliko vlogo $v$ razvoju turizma $v$ Brkinih ima Turistično informacijski center (TIC) $s$ sedežem v Ilirski Bistrici. Ustanovljen je bil leta 1998. Pred tem letom ne moremo govoriti o organiziranem turizmu na območju Brkinov. Leta 1998 pa so začeli v TIC s pripravo, ponudbo in izvedbo aranžmajev za zaključene skupine. Med te sodijo danes $v$ glavnem upokojenci. $V$ okviru ponudbe TIC so izdelane tudi štiri tematske poti: Brkinska sadna pot 1 in 2, Kettejeva pot ter Pot Toneta Kralja.

$\mathrm{Na}$ širšem območju Brkinov delujeta dve turistični društvi: v Slivju in Vremski dolini. Od tujih gostov prevladujejo v glavnem Italijani; ti prihajajo individualno, neorganizirano. Med njimi so priljubljeni gostinski lokali z domačimi specialitetami. Prav gostinsko ponudbo pa bi morali na celotnem območju Brkinov izboljšati oz. z njo sploh začeti. Npr. naselje Slivje nima gostilne in tako ne morejo niti za kratek čas zadržati številnih obiskovalcev 
jame Dimnice. Na drugi strani je primer gostilne Ambrožič v vasi Barka v severnem delu Brkinov, ki s svojimi domačimi specialitetami in gostoljubnostjo vsak vikend privablja številne italijanske goste, čeravno v okolici vasi ni ne naravnih ne kulturnih znamenitosti. Zaradi prehodne lege Brkinov med Italijo in Hrvaško predstavljajo prehodni potniki po Matarskem podolju potencialn vir zaslužka za intenzivnejši razvoj turistično gostinskih dejavnosti. Italijanske goste pa bi lahko zadržali v Brkinih tudi z večjo promocijo turističnega lova na divjad. Za Brkine je značilna velika gozdnatost (65\%), kar pogojuje večji stalež divjadi in ugodne razmere za rast gob. Ugodni rastiščni pogoji za gobe privlačijo veliko gobarjev, ki nekontrolirano pobirajo velike količine gob in s tem siromašijo gozdove. Tako gobarjenje $v$ Brkinih zaenkrat ostaja problem zaradi prevelikega števila gobarjev, lahko pa bi postalo del turistične ponudbe, se strinjajo domačini.

$\mathrm{V}$ ponudbo t.i. vikend turizma in izletniškega turizma bi lahko vključili tudi jahalno šolo in jahanje na terenu, pa že obstoječo geološko pot in tudi Evropsko pešpot E6 oziroma slovensko planinsko transverzalo (Škocjanske jame - Artviže - Markovščina). Brkinske ceste so $v$ večini asfaltirane z zelo malo prometa in zato kot take zelo primerne za kolesarjenje. Po Brkinih vodita kolesarski poti št. 16 in 17. Za šolske skupine in druge obiskovalce pa bi lahko uredili še različne učne poti: geomorfološko, geološko in etnološko.

Poleg bogate naravne dediščine imajo Brkinci tudi bogato kulturno dediščino, s katero bi lahko bolje promovirali Brkine. Pustni običaji so še danes velik dogodek v nekaterih vaseh Brkinov.

$\mathrm{Na}$ južnem delu Brkinov, natančneje ob cesti Reka - Trst, so v nekaterih vaseh ljudje ohranili poseben pustni običaj. V Hrušici ta običaj imenujejo škoromatija, pustne šeme pa škoromate. Škoromati so skupno ime za številne pustne šeme na območju Brkinov (prepeljuhar, cigan in ciganka, debeluhar, itd). Kot skupine nastopajo v Podgradu in Hrušici, do nedavna pa je bilo škoromatenje razširjeno na veliko večjem območju in tudi v daljšem obdobju.

V Harijah obnavljajo ljudski običaj "žegnanja konj" pred vaško cerkvijo Sv. Štefana, ki goduje dan po Božiču, 26. decembra. V ljudskem izročilu je Sv. Štefan - mučenik tudi zaščitnik konj. Cerkev je daleč naokrog edina posvečena temu svetniku, zato je bila nekdaj na Štefanov god shajališče konjarjev in tudi njihovih konj. Starejši vaščani še pomnijo, kako živahno je bilo v Harijah na Štefanovo. Po veliki maši, ki so se je praviloma udeleževali konjarji iz Harij, vseh sosednjih vasi, Brkinov in Čičarije ter bistriške doline, je sledila blagoslovitev konj, ki so jih za to priložnosti še posebej 
lepo pripravili in okrasili. Povojna leta so naredila svoje. Oblasti niso bile naklonjene takim in podobnim verskim navadam, pa tudi konj je bilo vse manj. Žegnanje konj, kot se je reklo, se je ohranilo še nekaj let po drugi svetovni vojni. Toda konj je bilo vse manj, zato so se ob koncu pri maši zbirali le konjarji sami, ki so se svojemu zavetniku oddolžili z denarnimi prispevki za cerkvene potrebe, konj pa niso smeli več blagoslavljati. Prijazen ljudski običaj je nato za dolga desetletja zamrl. Leta 1994 pa je skupina ljubiteljev konj iz Ilirske Bistrice, ki so se jim pridružili tudi domačini iz Harij in okolice, uspešno izvedla obnovitev starega običaja, ki je skoraj zbežal iz spomina in zavesti, čeprav le za skupino sedmih konj.

Primorsko numizmatično društvo Ilirska Bistrica je posebej za to priložnost skupaj s poštno upravo Koper pripravilo priložnostni poštni žig z ustreznim motivom in posebne barvne razglednice in dopisnico z motivom žegnanja konj. Leta 1998 se je zbralo kar 40 konj, leta 2000 pa 25 konj in 1000 obiskovalcev. Takšnih in drugačnih običajev bi morali obuditi še več, da ne bodo ostali le spomin na nekoč živahno družabno življenje v Brkinih, hkrati pa bi privabili številne obiskovalce in s tem pripomogli $\mathrm{k}$ razvoju Brkinov. Običaj je še vedno v navadi v Tatrah in Podgorju. To je običaj, da se po nedeljski maši družijo ljudje na plesu. Po plesu je kosilo. Za kosilo jedo juho iz pršutove kosti in pršut. V Pregarjah je bil običaj povezan s praznikom cerkvenega zavetnika Sv. Lovrenca, ki se praznuje 24. junija.

V novejšem času se na območju Brkinov uveljavljajo tudi kulturni dogodki, kot so Premska srečanja slovenskih pesnikov in pisateljev v Premu, kjer sta se rodila pesnik Dragotin Kette ter pesnik in esejist dr. Bogomil Fatur.

V okviru turistične ponudbe je potrebno posebej poudariti promocijo in trženje posebnosti Brkinov. Primer vasi, kjer so se tega že lotili so Slivje. Na sedaj že tradicionalnih Češpovih dnevih, ki se začanjajo vsako prvo nedeljo v septembru in jih organizira Turistično društvo Slivje, so lani prvič prikazali žganjekuho. Domačini radi povedo, da so prišli postopek žganjekuhe posneti celo z nacionalne televizije. Sicer pa se te osrednje vaške prireditve udeleži okoli 2000 ljudi od vsepovsod. Prireditev, ki se tri dni odvija od jutra do večera, domačini popestrijo $z$ gledališkimi igrami $v$ šotoru in $v$ jami Dimnice. Goste pa postrežejo s "češpovimi njoki". Na Češpovih dnevih se poleg prikaza žganjekuhe odvija še ocenjevanje žganja tudi iz sosednjih vasi. Slivarci kuhajo žganje v kotlih (20 -30l), ki so značilni samo za Brkine. Tudi to so Slivarci znali vključiti v turistično ponudbo. Lesene modele t.i. brkinskega kotla prodajajo na Češpovih dnevih. Domačini si tudi zelo prizadevajo ohraniti tradicijo oglarjenja in jo ponovno oživiti na prireditvi t.i. Češpovem vikendu. 
Poleg sliv ter z njimi povezanimi dobrotami in običaji so Slivarci v turistično ponudbo svojega kraja vključili tudi "štirne" v hišah - še eno od posebnosti Brkinov, ki si jo je možno ogledati v hiši pri Solarjevih (Slivje 29).

Slivje so še enkrat "popeljali v svet" s pomočjo nacionalne televizije, ki je prišla posneti edini še ohranjen kal in obrezovanje dreves. Po mnenju Slivarcev ostaja razvoj vasi $v$ rokah domačinov samih. Ti vidijo nove možnosti z odprtjem meje med Italijo in Slovenijo. Dali so že predlog za odprtje kampa, saj vidijo $v$ njem prihodnost, ker bi le - ta bil postavljen na območju med dvema mejama (italijansko - slovensko in slovensko hrvaško), kjer bo pretok ljudi z odprtjem meje vse večji.

Slivarci so lep primer pripravljenosti posameznikov za sodelovanje pri razvoju Brkinov. Kot so dokazali, lahko Brkini zažive s prodajo in promocijo brkinskih posebnosti: brkinskim sadjem (svežim in suhim), slivovko, slivovimi njoki in drugimi domačimi dobrotami (npr. žvižgovcem) in tudi vaškimi običaji, staro obrtjo, arhitekturnimi posebnostmi itd. V prihodnosti bi morali pri razvoju turizma poudarjati identiteto Brkinov kot celote. Prebivalci se sicer čutijo Brkince, vendar ni sodelovanja med posameznimi občinami. Pomembno bi bilo razvijati blagovno znamko Brkinov in skupno sodelovati pri aktivnostih za turistični razvoj. Na koncu naj omenimo še možnost razvoja kmečkega turizma. Pa tudi na antropogeni jezeri Klivnik in Mola ne smemo pozabiti, saj lahko nudita številne možnosti za razvoj rekreacijskega turizma. Vsako leto prvega aprila odprejo ribolovno sezono, kjer se zberejo številni športni ribiči iz bližnje in širše okolice.

Brkini imajo s svojo pokrajinsko in kulturno pestrostjo obilo možnosti za razvoj turistične dejavnosti, tako v obliki individualnega, neorganiziranega, kot tudi organiziranega turizma. Za razvoj in razvijanje tovrstne dejavnosti pa so potrebni volja in čas domačinov ter finančna pomoč in razumevanje države. 


\title{
Razvojne možnosti Brkinov (swot analiza)
}

\author{
Tabela 3: Razvojne možnosti Brkinov
}

Tab. 3: Brkini hills: development possibilities.

\begin{tabular}{|c|c|c|c|}
\hline Prednosti & Slabosti & Priložnosti & Nevarnosti \\
\hline $\begin{array}{l}\text { 1. } \begin{array}{l}\text { Sadjarska tradicija } \\
\text { 2. Čisto, ohranjeno } \\
\text { okolje (čist zrak, } \\
\text { mir, spokojnost) }\end{array} \\
\text { 3. Prehodna lega, } \\
\text { najbližja povezava } \\
\text { med Hrvaško in } \\
\text { Italijo po Matarskem } \\
\text { podolju } \\
\text { 4. Toplotni pas nad } \\
\text { toplotnim obratom } \\
\text { 5tik apnenca in fliša } \\
\text { (slepe doline), } \\
\text { pokrajinska pestrost } \\
\text { 6ulturna dediščina } \\
\text { (ohranjen spomin na } \\
\text { šege, navade in } \\
\text { običaje in njihovo } \\
\text { obujanje) } \\
\text { 7. pejsaž } \\
\text { 8. relief, slemenskost, } \\
\text { razglednost } \\
\text { 9. Brkinska identiteta } \\
\text { 10. Gozdnatost } \\
\text { 11. Gobe } \\
\text { 12. Veliko divjadi }\end{array}$ & $\begin{array}{l}\text { 13. demografska } \\
\text { gibanja } \\
\text { 14. razdrobljenost } \\
\text { med štiri občine } \\
\text { in nesodelovanje } \\
\text { med občinami } \\
\text { 15. neangažiranost, } \\
\text { nezanimanje } \\
\text { prebivalstva } \\
\text { 16. slaba } \\
\text { prepoznavnost } \\
\text { Brkinov } \\
\text { 17. odmaknjenost od } \\
\text { cestnega križa } \\
\text { Slovenije } \\
\text { 18. slaba dostopnost } \\
\text { 19. pomanjkanje } \\
\text { delovnih mest } \\
\text { 20. zaposlenost izven } \\
\text { Brkinov } \\
\text { 21. slaba izobrazbena } \\
\text { struktura } \\
\text { 22. slaba gostinska } \\
\text { ponudba } \\
\text { 23. bližina Postojne, } \\
\text { Lipice, Škoc. Jam } \\
\text { (konkurenca) } \\
\text { 24. nerazviti TIC } \\
\text { (premalo) } \\
\text { 25. ni informativnih } \\
\text { obcestnih tabel } \\
\text { (večjezične) } \\
\text { 26. nerazvito vaško } \\
\text { življenje } \\
\text { 27. slabša prehodnost } \\
\text { meje s Hrvaško po } \\
\text { letu 1991 } \\
\text { 28. reliefna } \\
\text { razčlenjenost in } \\
\text { zato manjša } \\
\text { prehodnost } \\
\text { 29. slaba kvaliteta } \\
\text { prometne } \\
\text { infrastrukture }\end{array}$ & 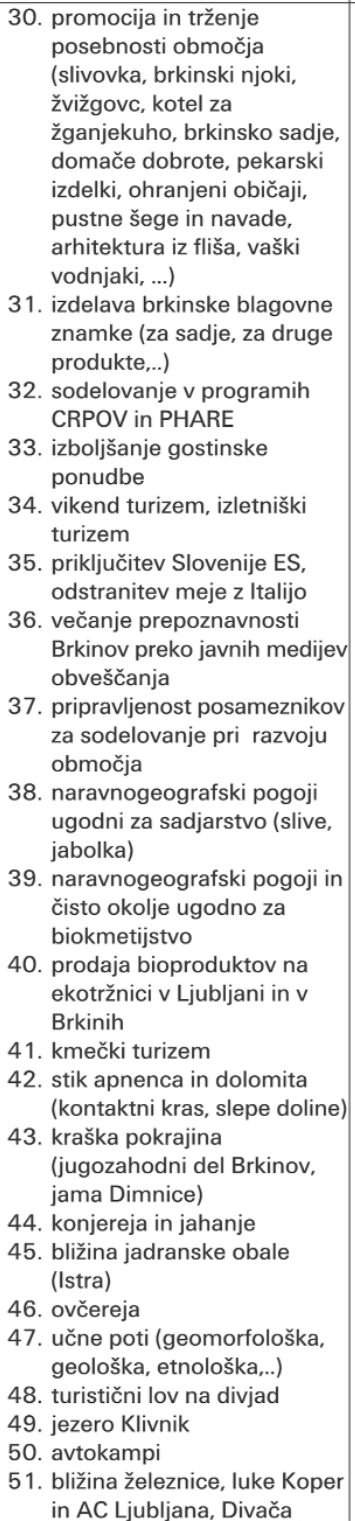 & $\begin{array}{l}\text { 52. staranje } \\
\text { prebivalstva } \\
\text { 53. odmiranje } \\
\text { oskrbnih funkcij } \\
\text { naselij oz. } \\
\text { nastanek spalnih } \\
\text { naselij } \\
\text { 54. ukinjanje osnovnih } \\
\text { šol } \\
\text { 55. zaraščanje } \\
\text { 56. propadanje } \\
\text { objektov (hiö, } \\
\text { gospodarskih } \\
\text { poslopij itd.) } \\
\text { 57. prikjučitev } \\
\text { Slovenije ES } \\
\text { 58. odseljevanje } \\
\text { 59. zled } \\
\text { 60. gobarjenje } \\
\text { (nenadzorovano) } \\
\text { 61. ovčereja (erozija } \\
\text { prsti) } \\
\text { 62. erozija prsti }\end{array}$ \\
\hline
\end{tabular}




\section{Zaključek}

V Brkinih je prisotna velika pokrajinska pestrost, saj v posameznih delih potekajo različni procesi različno intenzivno, kar moramo upoštevati tudi pri nadaljnjem načrtovanju razvoja regije. Poudariti pa je treba zlasti prisotno demografsko problematiko Brkinov (staranje prebivalstva, slaba izobrazbena struktura, izseljevanje prebivalstva) in strukturne probleme kmetijstva. Slednje bi bilo potrebno v prihodnje bolje proučiti. Smiselno pa bi bilo tudi nadalje raziskati družbenogeografski položaj Brkinov ter proučiti možnosti in nevarnosti za Brkine po vključitvi Slovenije v Evropsko skupnost. Ena najpomembnejših točk za nadaljnji pozitivni razvoj Brkinov je večje in usklajeno sodelovanje na medobčinski in na državno-regionalni ravni, za kar pa je potrebno najprej motivirati in aktivirati lokalno prebivalstvo.

\section{PROBLEMS OF SLOVENIAN RURAL AREAS. CASE STUDY OF BRIKINI HILLS}

\section{Summary}

It is difficult to define the borders of Brkini region. It is situated between submediterranean and continental part of Slovenia. This position is particularly evident in its climatic characteristics. Brkini region is both socially and geographically remote area. It has bad local connections due to its relief. Brkini region represents the hinterland of Italian port Trieste.

An analysis was made of ecological and landscape situation in order to be able to make suggestions about development possibilities of the region.

There were around 15000 people living in Brkini region at the end of 19th century. The population declined after the World war I and II because of Italian occupation at first, and later on as the region lost its function as Trieste's hinterland. Many emigrated and only 7116 inhabitants were living in Brkini in the year 2000. The central village is Pregarje. There is a high percentage of daily commuters and villages are becoming sleeping zones. The number of farmers dropped from $40,7 \%$ in 1961 to $9,1 \%$ in 1991 . The reason are emigrations of the young and Italian pensions of the old. There are good conditions for farming, especially fruit production, but a great percentage of farmland is overgrown, not cultivated.

Brkini region is devided among four communities (Hrpelje-Kozina, Pivka, Ilirska Bistrica, Divača) and represents an underdeveloped part of each of them. There is no co-operational strategic plan for its future. Brkini get the financial aid from two sources: PHARE and CRPOV. Part of the major tourist flow should be directed towards Brkini region at the information desks. There is a rich cultural and natural heritage to be discovered by visitors as well as specialities to be consumed or bought. 


\section{Viri in literatura}

ADAMIČ, F., 1990: Sadje in sadjarstvo v Sloveniji. Ljubljana, ČZP Kmečki glas.

BARBIČ, A., 1996: Brkini in Čičarija: družbenogospodarska podoba. Geografski vestnik 68 , str. $175-195$.

BRKINSKA SADNA POT 1 IN 2; KETTEJEVA POT;

PO POTEH TONETA KRALJA. 2001, TIC Ilirska Bistrica.

BRKINSKA SADNA POT. 1998, Društvo brkinskih sadjarjev.

GEOGRAFSKI ATLAS SLOVENIJE. 1998, Ljubljana, DZS, 360 str.

- http://www.brkini.net

- http://www.ess.gov.si

- http://193.2.252.94/ales/hruica.htm

- http://www.harije.si/galerija/stefanovo2000/slika15.html

- http://www.harije.si/galerija/vizita2000/slika 18.html

- http://www.harije.si/index2.html

- http://www.posta.si/slo/dz/filatelija-z.asp?Artikl=253

- http://www.skoromati.f2s.com

- http://www.sz-brkini.si/kazalo.html

KLEMENČıč, V., 1959: Pokrajina med Snežnikom in Slavnikom. Gospodarska geografija. SAZU. Ljubljana, 197 str.

KOLEDAR PRIREDITEV - april 2001. 2001, Turističčno društvo Postojna.

KRAJEVNI LEKSIKON SLOVENIJE. 1995, Ljubljana, DZS, CD-ROM, verzija 1.0.

POPIS PREBIVALSTVA 1991. Kategorija 1-1-08, Aktivno prebivalstvo, ki opravlja poklic, po dejavnostih.

SLOVENIJA - POKRAJINA IN LJUDJE. 1998, Ljubljana, DZS. 